\title{
Penyuluhan manfaat buah naga merah dalam menurunkan kadar gula darah pada penderita diabetes melitus
}

\author{
Eka Yudha Chrisanto ${ }^{1}$, Megah Rachmawati ${ }^{*}$, Rika Yulendasari ${ }^{3}$ \\ Program Studi Ilmu Keperawatan Universitas Malahayati
}

Corresponding Author: Megah Rachmawati Mahasiswa Program Profesi Ners Universitas Malahayati Email: megahrachmawati1@gmail.com

\begin{abstract}
Abstrak. Menurut International Diabetes Federation (IDF) pada tahun 2015, prevalensi jumlah DM di dunia sebesar 8,8\% dengan jumlah penderita sebesar 415 juta penderita dan pada 2040 diperkirakan akan meningkat sejumlah 642 juta penderita (10,4\%) (IDF, 2015). Sedangkan Indonesia menempati peringkat ke-7 penderita diabetes terbanyak di dunia. Salah satu buah yang dapat dimanfaatkan untuk perbaikan diet penderita diabetes melitus adalah buah naga yang memiliki keunggulan yaitu kaya serat dan antioksidan. Tujuan setelah penyuluhan dan demonstrasi, diharapkan pembuatan jus buah naga merah dapat untuk menurunkan kadar glukosa pada klien diabetes melitus. Adapun kegiatan yang dilakukan berupa penyuluhan menggunakan leaflet dan demonstrasi pemberian buah naga merah. Terdapat penurunan kadar glukosa pada klien diabetes melitus setelah pemberian buah naga merah selama 10 hari di Bandar Lampung. Dengan demikian, pemberian buah naga merah pada klien diabetes melitus sangat efektif dalam menurunkan glukosa.
\end{abstract}

Kata kunci: Buah Naga Merah, Gula Darah, Diabetes Mellitus

\begin{abstract}
According to the International Diabetes Federation (IDF) in 2015, the prevalence of DM in the world (8.8\%) with the number of sufferers at 415 million and 2040 it was expected to increase by 642 million patients (10.4\%). While Indonesia ranks 7 th most diabetics in the world. One of the fruits that can be used to improve the diet of diabetics is dragon fruit that has the advantage of being rich in fiber and antioxidants. The Purpose after counseling and demonstration, is expected to make red dragon fruit juice can reduce glucose levels in diabetes mellitus clients. The activities carried out in the form of counseling using leaflets and demonstrations giving red dragon fruit. There is a decrease in glucose levels in diabetes mellitus clients after giving red dragon fruit for 10 days at Bandar Lampung. Thus, giving red dragon fruit to diabetes mellitus clients is very effective in reducing glucose.
\end{abstract}

Keywords: Red Dragon Fruit, Blood Sugar, Diabetes Mellitus

\section{Pendahuluan}

Diabetes Melitus merupakan penyakit gangguan metabolik menahun akibat pankreas tidak memproduksi cukup insulin atau tubuh tidak dapat menggunakan insulin yang diproduksi secara efektif. Terdapat beberapa jenis dari diabetes melitus (DM) yaitu diabetes melitus tipe 1, diabetes tipe 2, diabetes melitus tipe gestasional, dan diabetes melitus tipe lainnya (IDF, 2015). Jenis diabetes yang paling banyak diderita oleh masyarakat adalah Diabetes melitus tipe 2 (ADA, 2013; Primahuda \& 
Sujianto, 2016) dan dapat muncul pada masyarakat dengan berbagai latar belakang, termasuk petani (Fandana, R. 2020).

Selain merupakan penyakit metabolik, DM juga merupakan penyakit global endemic. Insidensi diabetes secara global diperkirakan meningkat dari 366 juta jiwa menjadi 552 juta jiwa pada 2030 dan akan muncul dengan sendirinya sebagai tantangan kesehatan utama yang dapat diperlihatkan melalui data DM global (Shaw, Sicre, \& Zimmet, 2010; Ahmad \& Munir, 2018).

Menurut International Diabetes Federation (IDF) pada tahun 2015, prevalensi jumlah DM di dunia sebesar 8,8\% dengan jumlah penderita sebesar 415 juta penderita dan pada 2040 diperkirakan akan meningkat sejumlah 642 juta penderita (10,4\%) (IDF, 2015). Sedangkan Indonesia menempati peringkat ke-7 penderita diabetes terbanyak di dunia (IDF, 2015; Primahuda \& Sujianto, 2016).

Menurut Riset Kesehatan Dasar (Riskesdas, 2013), jumlah penderita DM Di Indonesia yaitu +12.191.564 jiwa. Prevalensi penderita DM di Provinsi Lampung yaitu 0,7\% dengan jumlah penderita 38.923 jiwa. Prevalensi diabetisi di Kota Metro adalah 1,2 \% dengan jumlah kasus 1.564 jiwa menurut (Dinkes Metro 2018) menempati peringkat 1 di Provinsi Lampung. Jumlah penderita diabetes di wilayah Kerja puskesmas rawat inap Banjarsari Metro sejumlah 668 kasus lebih tinggi dibandingkan Puskesmas Yosodadi sebanyak 360 kasus.

DM tergolong penyakit menahun, maka perlu adanya pencegahan komplikasi lebih lanjut (Perkeni, 2011; Ahmad \& Munir, 2018). Salah satu pencegahan komplikasi adalah dengan menjaga stabilitas gula darah pada diabetisi. Pencegahan komplikasi kronik tidak hanya dengan pengendalian kadar glukosa darah saja tetapi diperlukan pengendalian diabetes yang baik. Pengendalian diabetes harus secara dilakukan secara menyeluruh, termasuk kadar glukosa darah, HbA1c, kadar lipid (kolesterol Low Density Lipoprotein (LDL),High Density Lipoprotein (HDL), dan trigliserida (Semiardji, 2003).

Banyak penderita DM Tipe 2 tidak memahami dan menyadari kalau kadargula darahnya sudah tinggi. Hal inidisebabkan oleh beberapa faktor,diantaranya asupan makan terutamakarbohidrat, lemak dan protein, asupanobat, perilaku merokok, stres,dukungan keluarga, dan aktivitas fisik.Menurut Fox, ada beberapa hal yangmenyebabkan gula darah naik, yaitukurang berolah raga, bertambahnyajumlah makanan yang dikonsumsi, meningkatnya stres dan faktor emosi,pertambahan berat badan dan usia,serta dampak perawatan dari obat,misalnya steroid (Berkat dkk, 2018).

Penderita diabetes melitus dianjurkan untuk memperhatikan asupan karbohidat, protein, lemak dan serat karena penting artinya dalam pengendalian kadar glukosa darah. Akan tetapi, penderita diabetes melitus yang sudah menjalankan program diet ternyata ada yang tetap belum mampu mengendalikan glukosa darah dengan baik sehingga kadar hariannya tetap tinggi. Penyebabnya adalah kurangnya asupan sumber serat dan antioksidan.

Berdasarkan hasil penelitian yang dilakukan oleh Wiardani (2014) terhadap diabetes melitus ada perbedaan kadar glukosa darah sebelum dan sesudah pemberian terapi jus buah naga merah, pemberian terapi jus buah naga mampu menurunkan kadar glukosa dan kolesterol darah secara signifikan. Serat mempunyai kemampuan untuk memperlambat penyerapan glukosa dan lemak dengan cara meningkatkan kekentalan feses yang secara tidak langsung menurunkan kecepatan difusi sehingga kadar glukosa darah, profil lipid dan kolesterol menurun.

Antioksidan bermanfaat dalam menjaga elastisitas pembuluh darah, mampu memperbaiki sistem peredaran darah, menurunkan kadar glukosa darah dan kolesterol. Asupan serat dan antioksidan pada penderita diabetes melitus perlu ditingkatkan sehingga diperlukan perbaikan diet dengan menambah sumber buah-buahan seperti buah naga merah sebagai sumber makanan kaya antioksidan, serat, vitamin, dan karbohidrat dengan indeks glikemik rendah. Salah satu buah yang dapat dimanfaatkan untuk perbaikan diet penderita diabetes melitus adalah buah naga yang memiliki keunggulan yaitu 
kaya serat dan antioksidan. Buah naga dapat menjadi penyeimbang kadar gula darah karena buah ini mengandung berbagai macam antioksidan yaitu flavonoid, vitamin $\mathrm{E}$, vitamin $\mathrm{C}$, dan betakaroten yang memiliki kemampuan untuk menurunkan stress oksidatif dan mengurangi ROS(Reaktive Oxygen Species) sehingga dapat menimbulkan efek protektif terhadap sel $\beta$ pankreas dan meningkatkan sensitivitas insulin (Lianiwati, 2011).

Alasan saya memilih tempat penyuluhan kesehatan tentang diabetes melitus dan demontrasi tentang pemberian buah naga merah di Bandar Lampung ialah karena keluarga saya sendiri memiliki masalah kesehatan diabetes melitus, dimana tujuan umum dalam kegiatan diharapkan pemberian buah naga merah dapat menurunkan gula darah pada klien diabetes melitus. Dan tujuan khusus dalam kegiatan yaitu asuhan keperawatan, telaah jurnal untuk menentukan intervensi, evaluasi hasil aplikasi intervensi, perbandingan hasil intervensi pemberian buah naga merah.

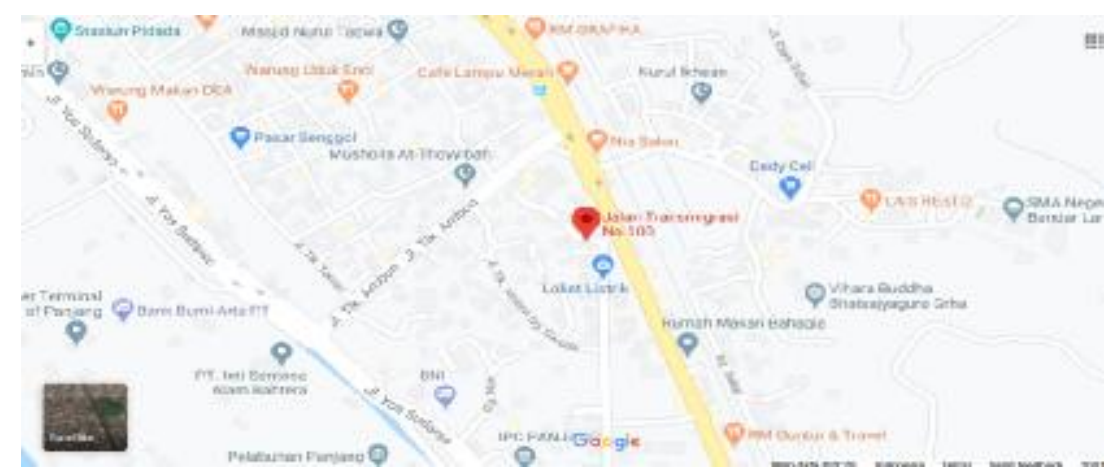

Gambar 1. Gambar: Lokasi penyuluhan dan demonstrasi

\section{Metode}

Tahap persiapan dari kegiatan adalah pembuatan pre planning, persiapan penyajian leaflet dan demostrasi, tempat dan alat-alat lainnya disiapkan oleh peneliti. Pembuatan leaflet dibuat pada hari Jum'at 12 Mei 2020, pada tanggal 13 Mei 2020 dilakukan penyuluhan, pengecekan gula darah, dan demostrasi pembuatan jus buah naga merah. Kegiatan ini dengan pemberitahuan kepada klien. Dan dilanjutkan penyuluhan penyuluhan, pengecekan gula darah, dan demostrasi pembuatan jus buah naga merah.

Peserta hadir 1 orang yaitu perempuan. Setting tempat sudah sesuai dengan rencana dan perlengkapan yang dilakukan untuk penyuluhan sudah tersedia dan sudah digunakan sebagaimana mestinya. Peran peneliti sebagai modertor, notulen, observer, dan juga fasilitator. Penggunaan bahasa yang dipraktekkan sudah komunikatif dalam penyampaianya, klien dapat memahami dan dapat mempraktekkan kembali yang di demonstrasikan.

Pelaksanaan kegiatan dilaksanakan pukul 09.00 s/d 09.30 WIB. Sesuai dengan jadwal yang sudah ditentukan. Hasil kegiatan menunjukkan bahwa Klien dapat memahami dan mengerti tentang pengertian terapi pemberian buah naga merah. Klien dapat memahami dan mengerti tentang tujuan dilakukannya terapi pemberian buah naga merah. Klien dapat memahami dan mengerti tentang manfaat dan teknik pembuatan terapi pemberian buah naga merah. Klien dapat memahami dan mengerti tentang langkah-langkah pembuatan buah naga merah 


\section{Hasil dan Pembahasan}

Pelaksanaan pemberian terapi pembuatan jus buah naga merah dilaksanakan pada tanggal 13 Mei 2020 s/d 23 Mei 2020. Penelitian dilakukan selama 10 hari, setelah dilakukan nya pemberian terapi selama 10 hari menurunkan gula darah klien. Berikut gambar pelaksanaan penyuluhan, pengecekan kadar gula darah dan pemberian terapi buah naga merah:
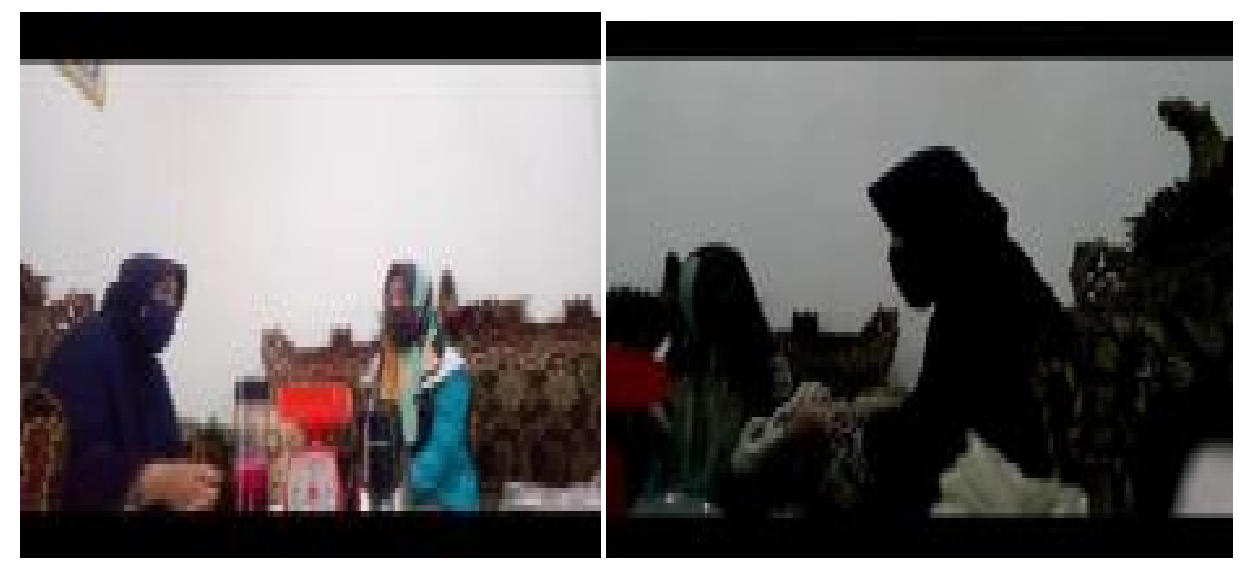

Gambar 2. Pelaksanaan penyuluhan, pengecekan kadar gula darah dan pemberian buah naga merah

Tabel 1 Evaluasi Penurunan GDS

\begin{tabular}{cccc}
\hline & Hari Ke 1 & Hari Ke 5 & Hari ke 10 \\
\hline Kadar GDS & $322 \mathrm{mg} / \mathrm{dl}$ & $274 \mathrm{mg} / \mathrm{dl}$ & $227 \mathrm{mg} / \mathrm{dl}$ \\
\hline
\end{tabular}

Pada tabel 1 dapat dilihat evaluasi hari terakhir pemeriksaan GDS pada klien diabetes melitus terjadi penurunan pada Ny. S, diperoleh data pada Ny. S sebelum diberikan asuhan keperawatan yaitu $322 \mathrm{mg} / \mathrm{dL}$ dan setelah diberikan intervensi pemberian buah naga merah selama kurun waktu 10 (sepuluh) hari dan dari hasil pemeriksaan di hari ke 5 didapatkan yaitu $274 \mathrm{mg} / \mathrm{dL}$ kemudian dilakukan pemeriksaan lagi di hari ke 10 yaitu $227 \mathrm{mg} / \mathrm{dL}$.

Sesuai dengan jurnal Wiardani (2014) yang berjudul Jus buah naga merah menurunkan Kadar Gkosa Darah Penderita DM Tipe 2 yaitu memberikan jus buah naga merah 100gram dalam 250ml jus selama 10 hari dapat menurunkan kadar glukosa pada penderita diabetes melitus tipe 2. Dapat disimpulkan bahwa tindakan pemberian jus buah naga merah dapat menurunkan kadar glukosa pada penderita diabetes melitus tipe 2. Sebagai alternatif, penderita dapat melakukan kegiatan latihan progressive muscle relaxation untuk kadar gula darah yang dimilikinya sehingga dapat meminimalisir terjadinya peningkatan risiko diabetes melitus(Wahyuni, D., \& Putri, R. 2020., Wahyudi, D., \& Arlita, I. 2019).

\section{Kesimpulan}

Terapi non farmakologi pemberian bah naga merah terbukti dapat menurunkan gula darah pada penderita diabetes melitus. Hal ini membuktikan beberapa hasil penelitian yang pernah dilakukan kepada klien dengan diabets melitus, bahwa pemberian bbuah naga merah dapat dijadikan alternatif perawatan diabetes melitus yang murah, mudah, dan aman. 


\section{Daftar Pustaka}

American Heart Association (AHA) (2014). Cardiovascular Disease and Diabetes. Tersedia dari: URL: HYPERLINK http:/www.org/HEARTORG/conditions/Diabetes/whyDiabetesMatters/Cardiovascular-DiseaseDiabetesUCM 313865 Article.jsp

Darmono. (2007). Diabetes Melitus Ditinjau dari Berbagai Aspek Penyakit Dalam. Semarang: CV Agung Semarang

Dinas Kesehatan Provinsi Lampung, (2013). Profil Kesehatan Provinsi Lampung Tahun 2013.

Fandana, R. (2020). Diabetes Mellitus Pada Petani. Wellness And Healthy Magazine, 2(1), 1 - 4 . Retrieved from https://wellness.journalpress.id/wellness/article/view /21001

Hapsari, A. I., Purwanto, B., \& Wiboworini, B. (2017). Pengaruh Konsumsi Buah Naga Merah (Hylocereus Costaricensis) Terhadap Kadar Glukosa Darah Puasa dan Kolesterol-Ldl pada Penderita Dm Tipe 2.Jurnal Gizi dan Kesehatan, 2(1), 28-41.

Hasdianah, H.R. (2012). Mengenal Diabetes Melitus pada Orang Dewasa dan. Anak-Anak dengan Solusi Herbal. Yogyakarta: Nuha Medika.

Hastono, Sutanto. (2007). Analisa Data Kesehatan. Jakarta: Universitas Indonesia

Hidayati, A. R., \& Suprayitno, E. (2017). Pengaruh Buah Naga Terhadap Kadar Glukosa Darah Pasien Diabetes Melitus Tipe II di Puskesmas Temon 1 Kulon Progo Yogyakarta.

Kemenkes RI, (2014). Infodatin Diabetes. $\underline{\text { http:/www.depkes.go.id/resources/ }}$ download/pusdatin/infodatin/infodatin-diabetes.pdf

Kemenkes RI.(2013). Profil Kesehatan Indonesia Tahun 2012.

Kristanto. 2008. Buah Naga Pembudidayaan di Pot dan di Kebun. PenebarSwadaya. Jakarata

Kumar V, Abbas AK, Fausto N. (2007). Buku Ajar Patologi Robbins.Edisi 9. Philadelpia : Elsevier Saunders

Nadimin. (2009). Pengaruh Pemberian Diit Dm Tinggi Serat Terhadap Penurunan Kadar Gula Darah Pasien Dm Tipe-2 Di Rsud Salewangang Kab. Maros, Jurnal Keperawatan.14-19.

PERKENI. (2011). Konsensus pengelolaan diabetes melitus tipe 2 di Indonesia 2011. Semarang: PB PERKENI

Powers, A.C., (2010). Diabetes Mellitus. In: Jameson J.L. Harrison EndocrinologyEd 2. USA: McGraw-Hill Companies, Inc.

Price SA, Wilson LM. (2006).Patofisiologi. Konsep Klinis Proses-Proses Penyakit. 4ed. Jakarta: EGC

RISKESDAS. (2013). Riset Kesehatan Dasar Tahun 2013. Jakarta: Badan Penelitian dan Pengembangan Kesehatan, Departemen Kesehatan, Republik Indonesia.

Smeltzer dan Bare. (2007). Buku Ajar Keperawatan Medikal Bedah,. Edisi 8 BrendeG.Bare; Alih Bahasa, Agung Waluyo, dkk. Jakarta : EGC

Sudoyo, A.W., ed. (2009) Buku Ajar Penyakit Dalam. Jilid III. Edisi ke 4. Jakarta: Fakultas Kedokteran Universitas Indonesia

Tjokroprawiro. (2002). Diabetes Mellitus Klasifikasi Diagnosis dan Terapi, Edisi ketiga PT Gramedia Pustaka Utama. Jakarta.

Wahyudi, D., \& Arlita, I. (2019). Progressive Muscle Relaxation Terhadap Kadar Glukosa Darah Diabetes Melitus Tipe 2 Terkontrol dan Tidak Terkontrol. Wellness And Healthy Magazine, 1(1), 93 - 100. Retrieved from https:/wellness.journalpress.id/wellness/article/view/w1112

Wahyuni, D., \& Putri, R. (2020). Persepsi pencegahan penyakit pada keluarga yang memiliki riwayat keturunan diabetes mellitus tipe 2. Wellness And Healthy Magazine, 2(1), 193 - $197 . \quad$ Retrieved from https://wellness.journalpress.id/wellness/article/view/21027 
Waspadji S. (2009). Buku Ajar Penyakit Dalam: Kaki Diabetes, Jilid III, Edisi 4,Jakarta: FK UI

Wiardani, N. K., Moviana, Y., \& Puryana, I. G. P. S. (2014). Jus Buah Naga Merah Menurunkan Kadar Glukosa Darah Penderita DMT2. J. Skala Husada, 11, 59-66. 